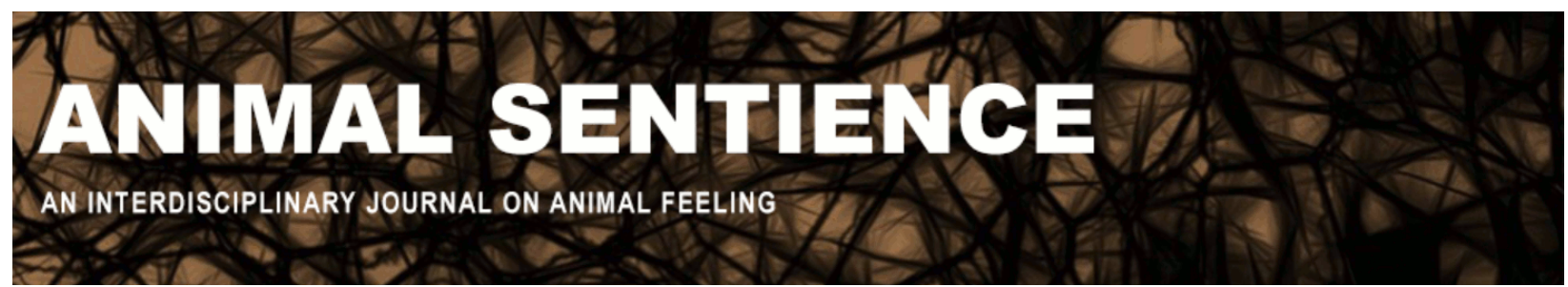

Phillips, Clive (2019) Sacrificial lambs. Animal Sentience 25(2)

DOI: $10.51291 / 2377-7478.1433$

Date of submission: 2019-05-07

Date of acceptance: 2019-05-15

(c) (i)

This article has appeared in the journal Animal

Sentience, a peer-reviewed journal on animal

cognition and feeling. It has been made open access,

free for all, by WellBeing International and deposited

in the WBI Studies Repository. For more information,

please contact

wbisr-info@wellbeingintl.org.

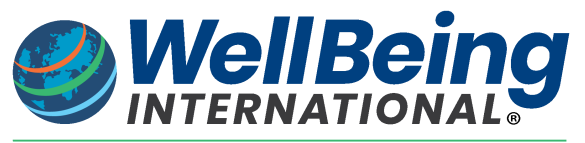

SOLUTIONS FOR PEOPLE, ANIMALS AND ENVIRONMENT 


\title{
Sacrificial lambs
}

Commentary on Marino \& Merskin on Sheep Complexity

\author{
Clive Phillips \\ Centre for Animal Welfare and Ethics \\ University of Queensland, Australia
}

\begin{abstract}
Sheep evolved from the mouflon as mountain animals, able to escape predation by leaping between rock ledges. Their defense was their agility. Humans brought them to the plains, where the agility was less useful, but their lack of aggression, speed or weaponry against predators made them a prime target to become one of man's meat providers. A perfect animal in many ways, with extraordinary perceptive powers and some remarkable cognitive skills, they are often treated with complete disregard for their welfare. Yet sheep themselves won't tell us this, for a sheep that alerted others to its weakness really would be stupid. Scientists must ask why we sometimes treat them as non-deserving of moral consideration when it comes to their use in agriculture.
\end{abstract}

\footnotetext{
Clive Phillips, Professor of Animal Welfare, School of Veterinary Science, University of Queensland, does research on animal welfare and ethics and policy development, particularly the live export of cattle and sheep from Australia. His work has led to a review of the use of calves in rodeos. He regularly advises advocacy groups in Australia and abroad on welfare issues. Website
}

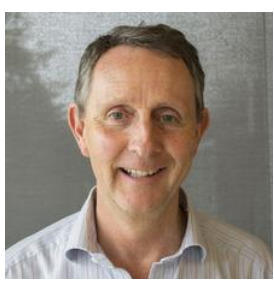

Sheep, more than any other livestock species, were at the foundation of our modern agriculture when they came to be domesticated about 12,000 years ago in the Near East (Clutton-Brock 1999). Even the Latin name, Ovis aries, conjures up images of the ancient people of that region paying homage to their sheep by naming a constellation after them. Since then that 'fertile crescent' is no longer so fertile, but the demand for sheep meat as a staple in the diet of that part of the world has persisted, offering an opportunity for distant countries like Australia to send millions of sheep each year for slaughter.

Marino \& Merskin's (2019) remarkable review captures in one target article the juxtaposition of the images of sheep as quiet, timid and servile in most people's eyes, with the increasing evidence from scientists that sheep have some extraordinary perceptive powers and an inner psychology that is in some respects just as complex as that of primates. I suspect this may be true of most species; however, scientists do have a duty to consider the enormous harm that we do to sheep in our modern agricultural systems. Scientists must ask why we sometimes treat them as non-deserving of moral consideration when it comes to their use in agriculture.

Sheep evolved as mountain animals, from the mouflon, able to escape predation by leaping between rock ledges. Their defence was their agility. Humans brought them to the plains, where the agility was less useful, but their lack of weaponry against predators, aggression or even an ability to run fast, made them a prime target to become one of man's meat providers. 
Sheep have some remarkable properties that have been demonstrated by scientists in the last 20 years - recognition of faces over long periods of time, an ability to see predators a kilometre away, intricate personality traits. None of these comprise intelligence per se, but isn't asking people how intelligent sheep are simply cementing the anthropocentric view of intelligence as an ability for advanced cognition? Sheep are as intelligent as they need to be; being more intelligent would be stupid, or at least maladaptive, since the additional energy requirements of advanced cognition would render them uncompetitive ecologically. Now they are brought to us, literally, as the sacrificial lamb in our inherited carnivorousness.

What value will Marino \& Merskin's review have in combining our perception of sheep with their perception of the world? It should alert many to the contradictory nature of their plight: a perfect animal in many ways that is often treated with complete disregard for their welfare. Yet sheep themselves won't tell us this, for a sheep that alerted others to its weakness really would be stupid. However, we know this with absolute certainty, for science has not only told us what sheep perceive, it has told us what harms sheep and has confirmed that we are harming them on a large scale. Sheep travelling thousands of kilometers to slaughter are experiencing heat, ammonia and motion, to name just some of the problems, of sufficient severity to cause stress (Cockram 2014). If we, as a species that controls the fate of many animals and species on the planet, have any value at all, it is surely to inject some equity into the management of the species from which we derive benefit.

Marino \& Merskin's target article should be compulsory reading for all politicians, managers, handlers, transporters and others involved in sheep management.

\section{References}

Clutton-Brock, J. (1999). A natural history of domesticated mammals. Cambridge University Press.

Cockram, M. S. (2014). Sheep transport. In Grandin, T. (Ed.), Livestock handling and transport: Theories and applications. Cabi.

Marino, L. and Merskin, D. (2019). Intelligence, complexity, and individuality in sheep. Animal Sentience 25(1) 